\title{
$4373 a$
}
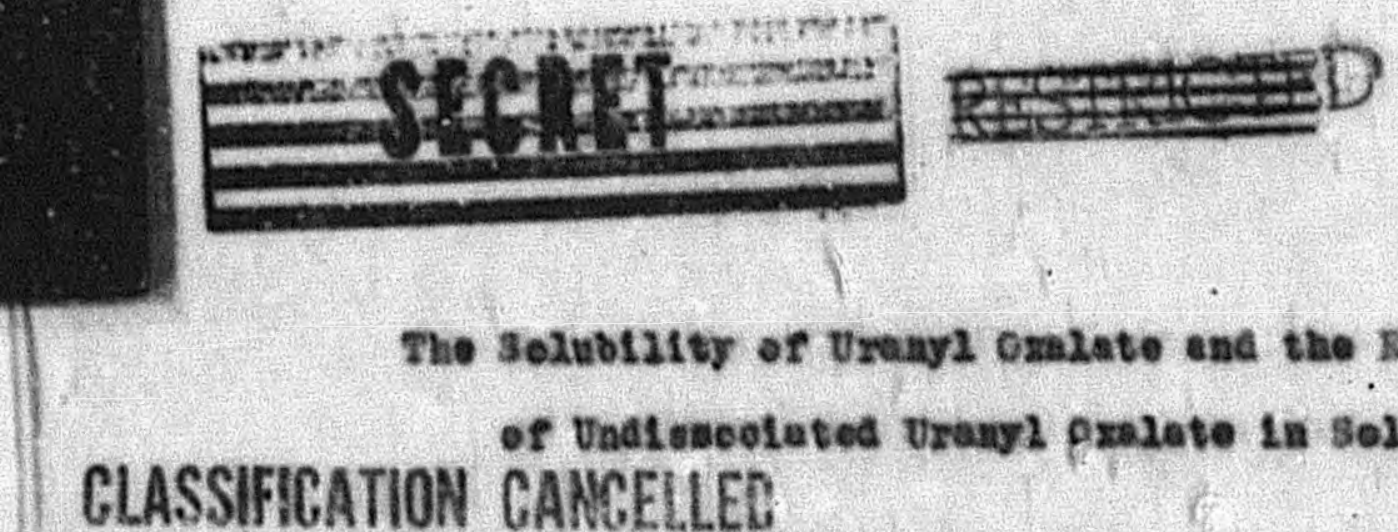

\section{CLASSIFICATION CAMCELLLER}

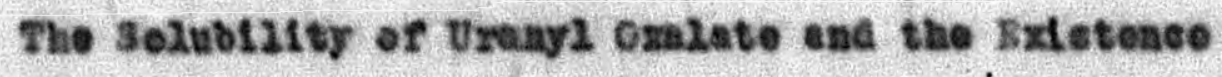

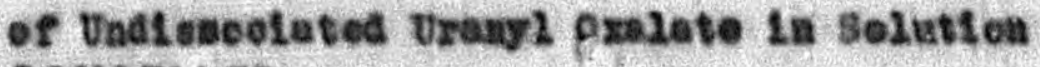

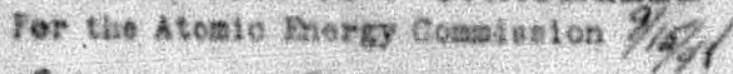

Charlie 2. xevix

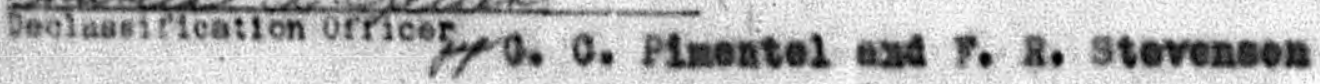

\section{Septembew 8, 1945}

Fing doourent hag then revioxed of the

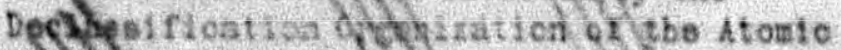

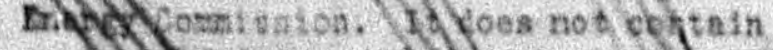

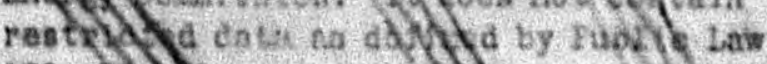

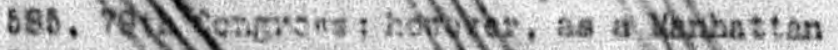

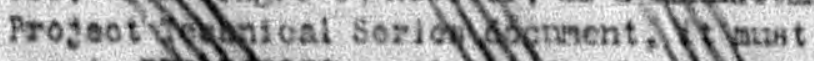

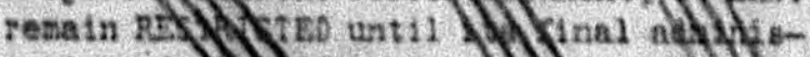

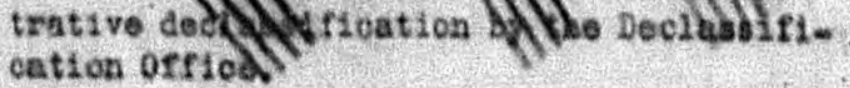
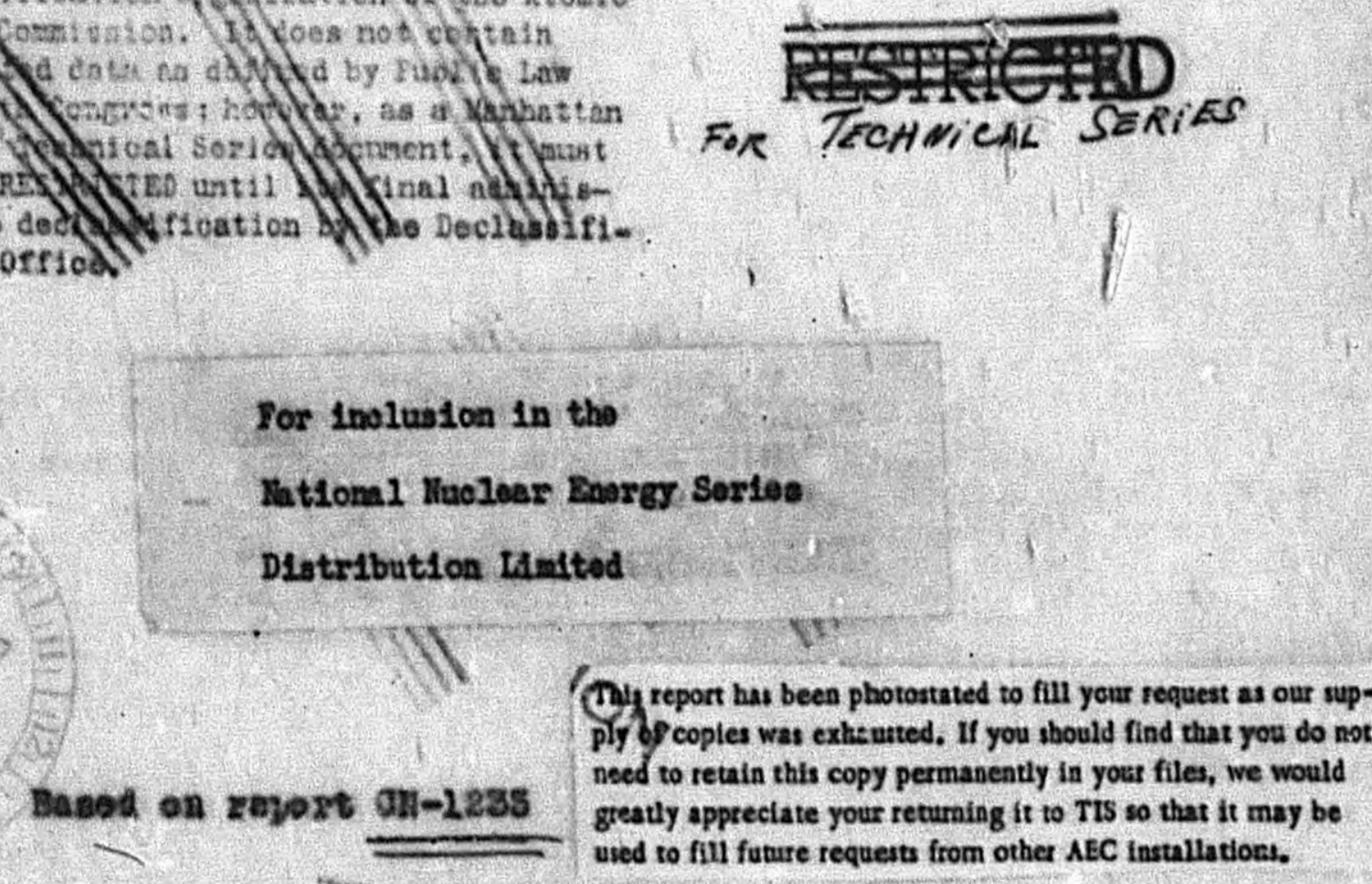

OMy report has been photostated to fill your request as our supph b coples was exheuted. If you should find that you do not used to fill future requests from other AEC installations.

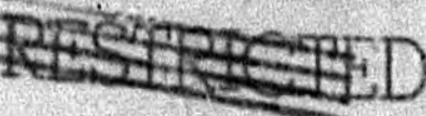


Asatrant

The solubsuty of the aolsa, $\mathrm{wO}_{2} \mathrm{O}_{8} \mathrm{O}_{4} \cdot \mathrm{xtl}_{2} \mathrm{O}$, was neasured at various acld and urangl nitrate cosecatraAlone. The results of the neasurezents psove the

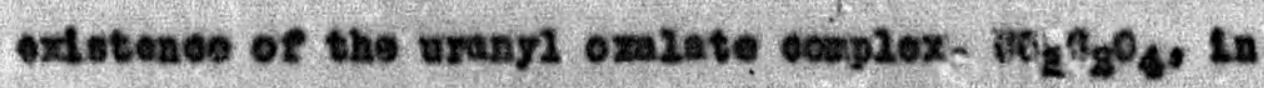
selutlons contalning exceas vot?

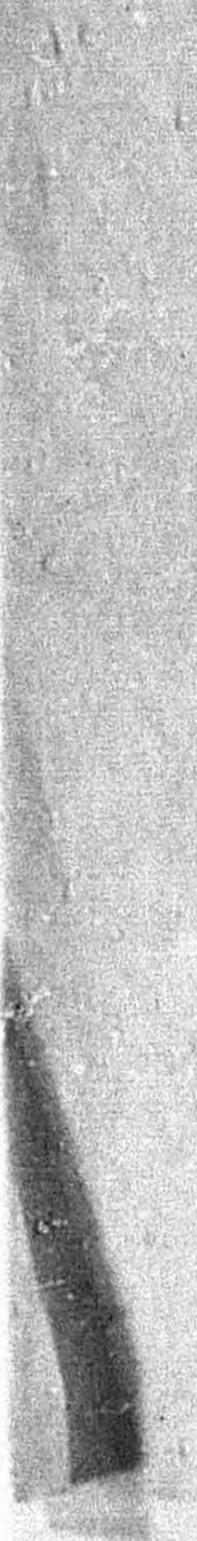


The Solubsitty of Vrangl exalwte and the sxisteace of Vnatssoetated Vxangh oxalate in Solution

The solubi21ty of $\mathrm{E0}_{2} \mathrm{O}_{2} \mathrm{O}_{4} \cdot \mathrm{xa}_{2} \mathrm{O}$ was measured at sereral attrto a old coneentxations and severel uranyl attirate conoentratlons. Fron the Iinted Ineluenee of seta concentration and urany3 nitrate conecstration on colubluty it was conoluded that nearky all of the oxalete fi rolution ves

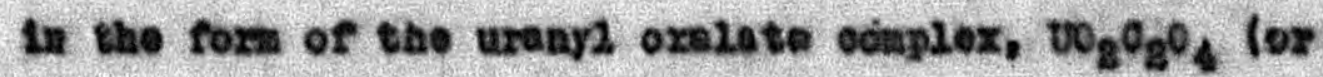
$\left.\left(00_{2} \mathrm{C}_{8} \mathrm{O}_{4}\right)_{\mathrm{n}}\right)$.

The eouposition of the sol1e phase (urenyl oxa1ete) present in the solubility measuremente vas ofternthed. Fe. preolpltate wes obtalned fron a solution 0.5 . . In

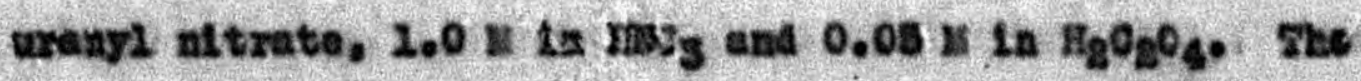
solid vas aucked ary on \& sintered cless filter and then atesolved in 6-7 II moge Kqual allquots were taken for exalate titretion wth of ${ }^{-}$(eee below) and for 1 enition to Vglge In the thind expertient the preelpltate wes weahed

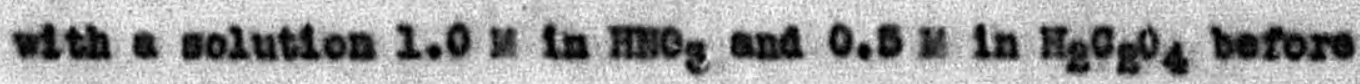
Alssolving. Tho results ase gtves in Teble d. Thoy ind-

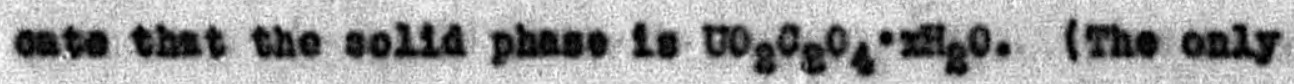
bydzato 21 sted in the Ifterature is the trihydrete). cauntitative tibxatlon of the total oralate preseat In solutton was used to scasure the solublitty of urangl Total oxalate inoludes that in any usengl oxalate conglezes as wend as $\mathrm{B}_{2} \mathrm{C}_{2} \mathrm{O}_{4}$, oto.. 
TABLS 2

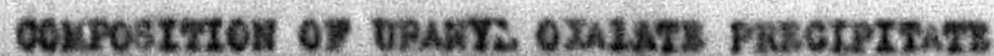

\begin{tabular}{|c|c|c|c|c|}
\hline sixpt: & 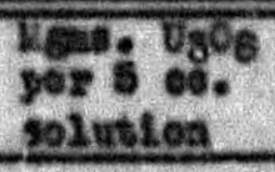 & 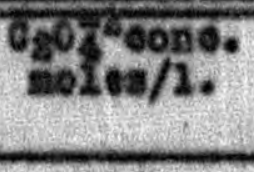 & 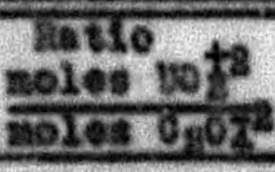 & Remaris \\
\hline 2 & 119.2 & 0.0725 & 1.073 & 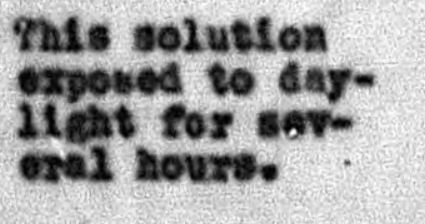 \\
\hline e. & 63.4 & 0.0484 & 1.008 & $\left(2 e^{2}\right.$ \\
\hline 8 & 47. 2 & 0.03661 & 0,075 & $\begin{array}{l}\text { Preedpitate washed } \\
\text { with } \mathrm{ItO}_{5}-\mathrm{I}_{2} \mathrm{O}_{2} \mathrm{O}_{4} \\
\text { solueton. }\end{array}$ \\
\hline
\end{tabular}

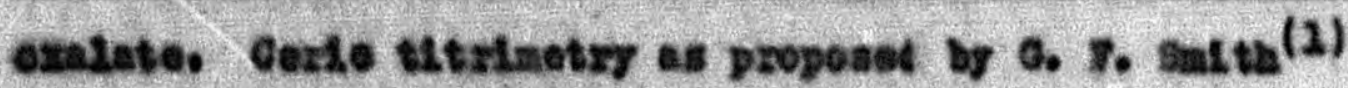
proved epplteable. A satiafaetory tftratson is obtalined by adths en exosse of etenderd sanorfus hexanltratecerete solutlon, beatlag $2 t 50-6050$. for $10-15$ minutes, ead back Citrating the excess oerato at rock teaperature with standard ferrous acbondis sulfate solutlen. Ittro-ortho-pheasnthroline

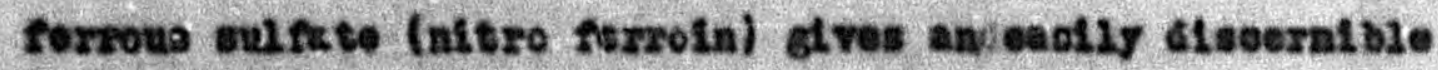
color ehange in the presence of $0.2 \mathrm{~V}$ urengl nitrate, whteh

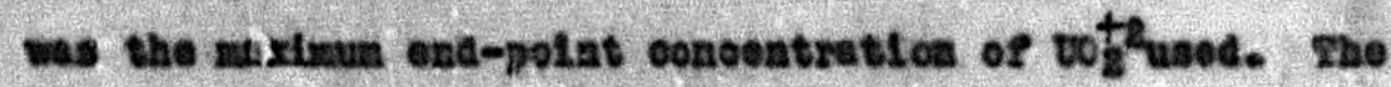

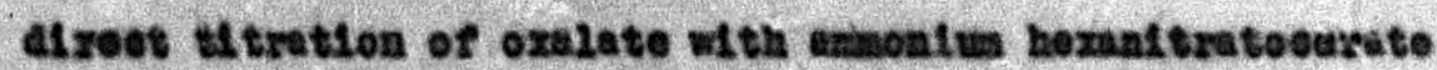
In the gresence of urany $10 \mathrm{n}$ gave a toding oxd polnt. Thts wes at least partialiy due to an spprectable eacrant of reduoIng materles in the uragy nitrate. Whs reduelng naterlal necessitated correotions in all caleulatlong. The blanir tlesatloas were steliar in every respeot to the taund tItratlon ezoept that no oxalate was ected. 


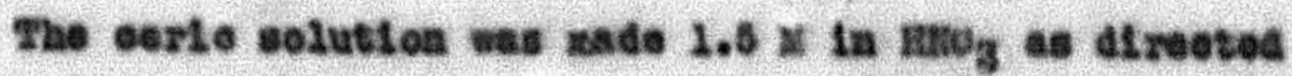
by O. F. Sated(a) to eacure stablity. Boatum ozalate vas esed as a. primary stantart. The forrous solution was chenked daliy agatast the standard carto solutlok.

Tae solutiona undex Investlgation $\left(0.25-1.0 \mathrm{y} \mathrm{w}_{\mathrm{g}}^{\mathrm{t}}\right.$

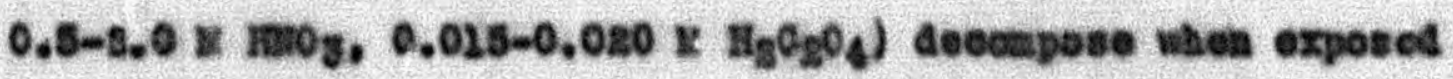
to 21 cht. It was expertwenta21y veriftse that four hours exposure to very strons artsflolu2 21 ght was suffloleat to

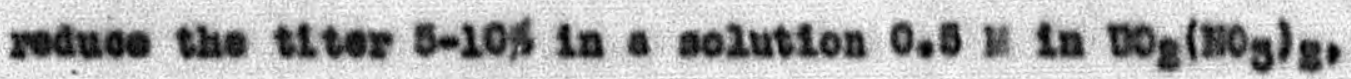

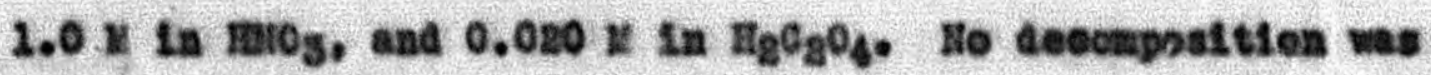
observed on a dupliaste sample lert in tho derk for sevsa hours before t1tration. In same of the earky experiments the seanples withdrewn for analygle were expoeed to 21 cht for sene time before betng titrated. A22 values from eaples that had pore than en hour and a hale of exposure vere Alsesrded. Thereafter, AL solutions wexe lost in the cark whle analung titration, alzowing about ten mfintes exposurs auring witharana2. This prectution elisInated the Ructuations provioualy observed eas brovght the Ceviatlons cown to lese than 0.04 on Later samplet. Ho precathions were taken to shlexd the solutions in the thermostat, einee the rate of cecompotitlen due to exposure to 24 eht 1 s very ands compered to the zato of solution of the uxangl oralate.

To be eertaln that equilibrlum was estabilahed, tho solublisty was deternined both from the supersaturated and the ungaturated stde. The uranyl nitrate and the bitrie 
cold were flrst stxed snd brovght to the correct texperetuse. Thea elther oxalle cesd or colld uranyl oxalate was adted In ardar to approach the equilibrtum by preolptitation or by selutlos of the solid phase. Solsd urangl oxalate was propared by preolpltetiea from a solutiea alaliar to that in ublah 1 t was to be esed.

The solubulty cata sa presented in rable e. Indieated It th eheh oxelate concentration Is the elapoed tise between the etart of the experisent and athdraxal of the saxple. Fhe averse oxalate concentration for each experteent is Ava elesg with the average deviation.

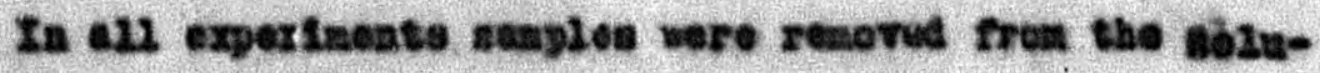

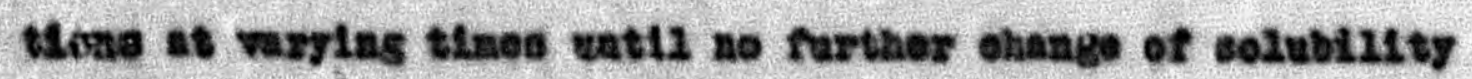
ses observed. It ean be seea in rable a that equllibrle Is rapleiy reached from the unsaturated side and is fatriy seplaly established in the superaeturated solutloa after oryotalization segins. Cxpresilzation in the frast cxperteeat eotually cosconoed botween 2 apd $\$$ houra after atxilts of the solutioas. Furtars, 14 is aeen that true equilsbrtua was obtalned es both sats of cate approech the sabe Fulue for the solubility.

In Fcble 3 the solublitty values obialaed in each pats of experisoate (atarting tren opposite alles of oquiliartua) are avareged. The results axe axranged to show the erfect of urangl altzato coneentretton, Mtrle edd coneestretlon esd teapersteure.

Fho results, ahowa in part I of rable 8 lead to the strprielas conoluston that over a four fold change sa the 
Ther 8

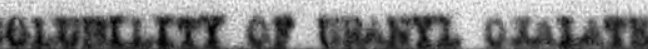

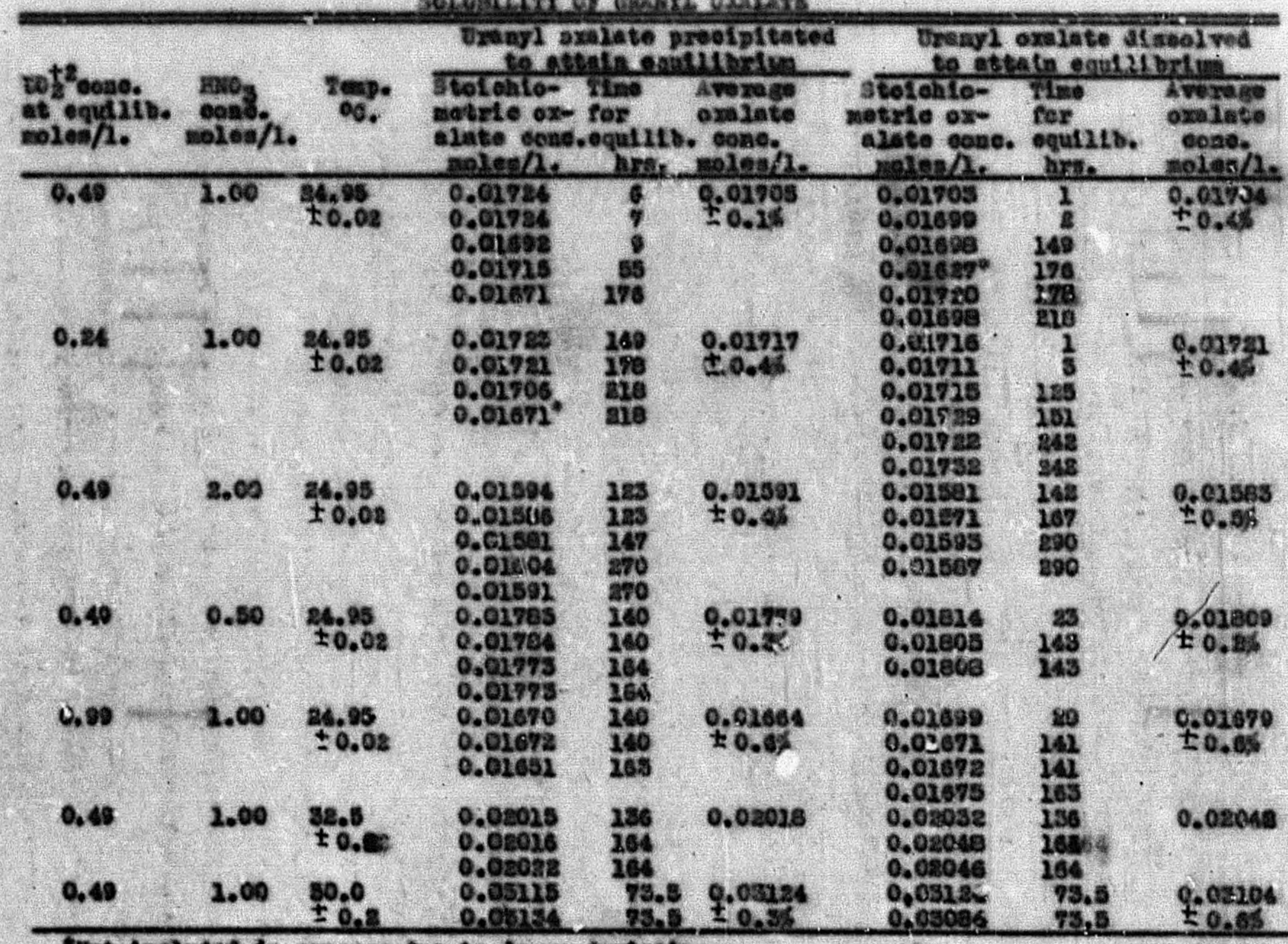

Hot Inaluded in averago ene to large dovtactone

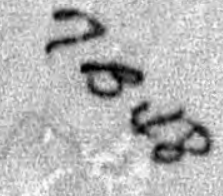


zunx $s$

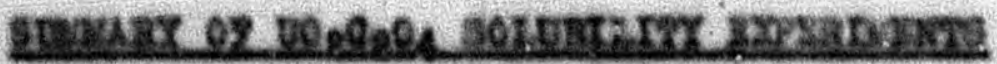

1. Brfecs of Vrangh mitrate doneentration

(mog) $1.00 \mathrm{molas} / \mathrm{h}$.

romp. $44.25^{\circ} \pm 0.02^{\circ} \%$.

$\left(0_{2}^{+2}\right) \quad 0.24 \quad 0.49 \quad 0.90 \quad=0100 / 2$.

(rotal $_{\text {orazate }} 0.0298 \quad 0.0290 \quad$ C.0107 moles/2.

II. Efreet of $\mathrm{ENO}_{3}$ Goncentsetion

$$
\begin{aligned}
& \left(w_{2}^{+2}\right) \quad 0.49=162 / 1 / \\
& \text { Teap. } 24.95^{\circ} \pm 6.08^{\circ} 0 \text {. }
\end{aligned}
$$

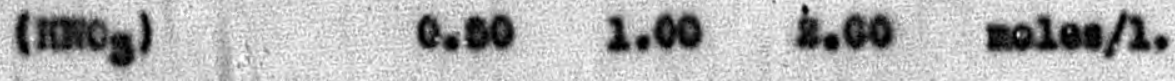

$$
\begin{aligned}
& \text { (Total oxalate) } 0.0179 \quad 0.0190 \quad 0.0159 \text { moles/1. }
\end{aligned}
$$

III. zefrest of Feaperature

$\left(\mathrm{vo}_{\mathrm{B}}^{+\mathrm{s}}\right) \quad 0.49 \mathrm{moles} / \mathrm{h}$.

(nnog) $1 ., 00$ soles/1.

Teap. $\quad 24.9359 .5 \quad 50.0 \%$ \%०.

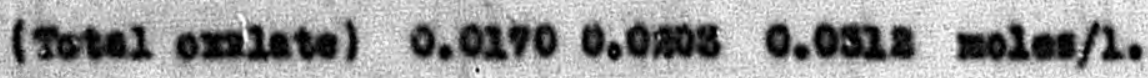


erariy altzete eoneentretion the sulublitiy of ureny oxslote wrted to leas then thuo percent. Alse, a four fold ohenge is nttrie ade coneentrettion produend onty a 125 shange In the so2ubiatr. These reots seen bet expletaed by the aswuaption thet aear2y all of the oxalate In solution la tled us by uray lons as o wengl oxelate

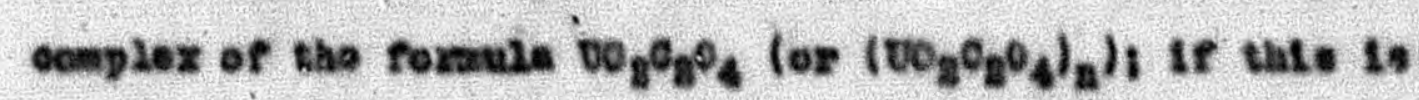
case, the alorle sole and urenyl eoneentratlens would beve no effeet on the salubthty iaxeopt for lente atrength erreats.

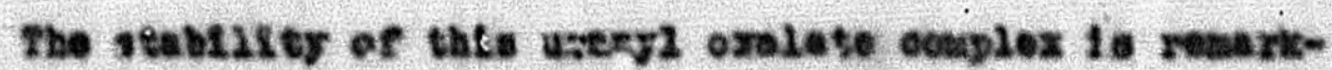
able, but It stould be rezenhered that the solution aleays eontatnad a laxge exoess of uranyl loka. at mallex eenosatrations of urany $10 \mathrm{as}$, the eomplex wolle tend to

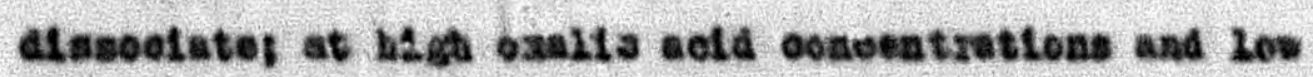
eoldtty, hither oraplexes would protably rom.

It Ia listeresting to note that the higd solubisty of callssoefatod urengh oxalate sets a ratker hich limit to the mintawa total soluhiltty of the serpound in aqueous solutson. Thus at $25^{\circ} \mathrm{G} .$, under any condltion, the solubility anss be at least 0.027 acles/14ter if the sere eolld phase as used in the above expertneats la present. A search of the 21terature reveals this to be the case exoept for sas 1 deviatichs due to salt efreste. 


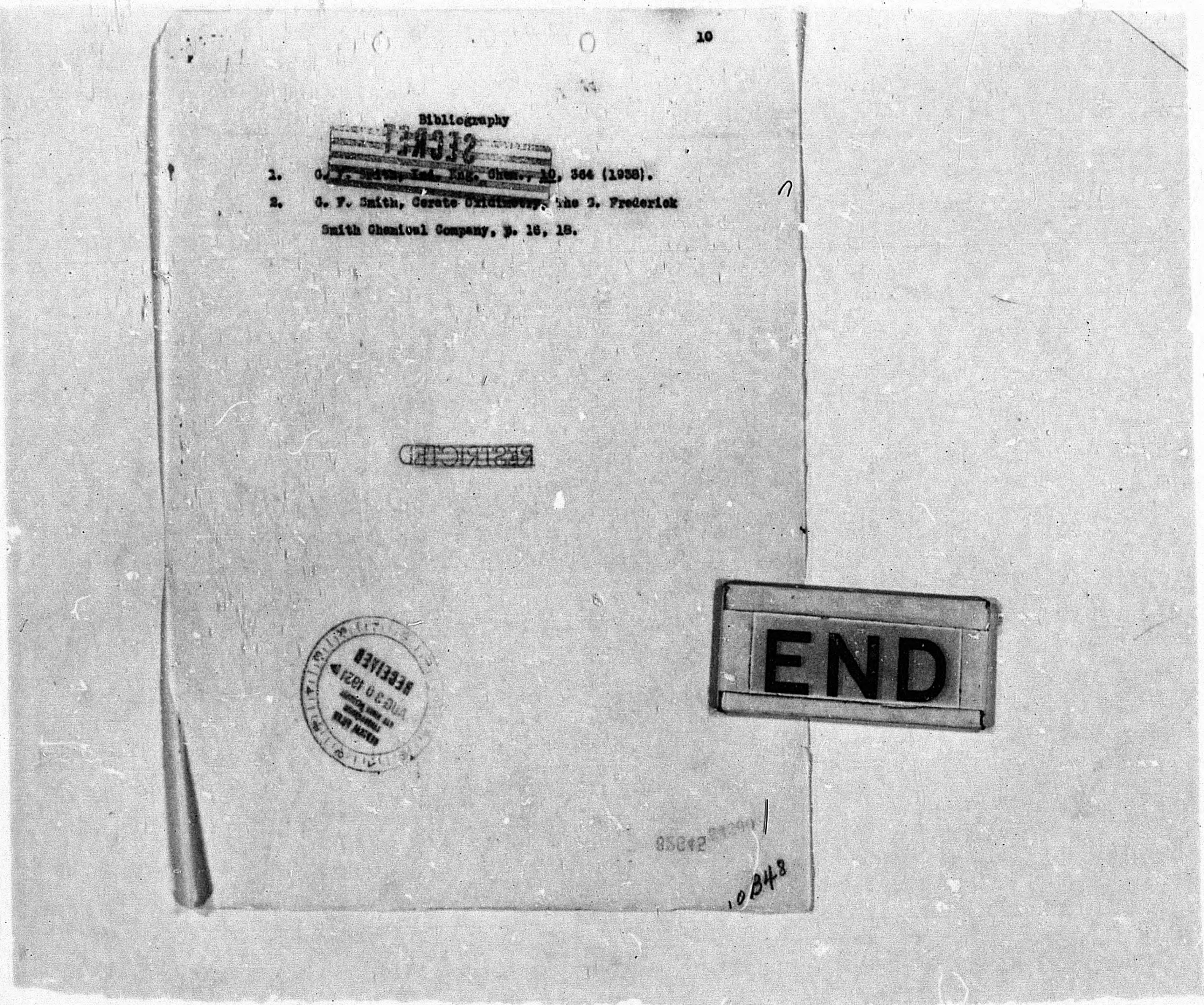

